\section{GEOLOGICAL MAPS}

\section{Atlas zur Geologie}

Edited by Erich Bederke and Hans Georg Wunderlich. (Meyers Grosser Physischer Weltatlas, Band 2.) Pp. xix +75 . (Bibliographisches Institut $A G$ : Mannheim, 1968.) 25 DM.

Since the end of the Second World War there has been an explosion in the accumulation of facts about the structure of the Eurth. This has arisen not so much from the slow dotailed mapping of the exposed rocks of the continental masses as from the application of the techniques of airphoto interpretation, and of air and ship-borne geophysical methods. Two decades ago, knowledge of the geology of the occan basins was minimal, acquaintance with the structure of most continental shelves slight and large areas of the land surfaces were geologically unexplored. The spectacular progress made in exploring the atom on one hand and universal space on the other, has perhaps tended to obscure the great advances made in understanding our planet.

Perhaps for the first time in the history of scienee, the occasion is right for a general synthesis in atlas form. The volume by Bederke and Wunderlich, modest by comparison with some current atlases, fulfils a real need. It forms the second volume of a series, under the title of Meyers Larger Physical World Atlas, which also covers biogeography, soil distribution, geomorphology, climate, orography, oceanography and the skics.

The page size permits the presentation of projections at the scale of $1: 80 \mathrm{~m}$ of world stratigraphy and tectonics covering the double page, while the single page accommodates projections at $1: 130 \mathrm{~m}$ illustrating topies such as the distribution of seismic epicentres, of coal and petroleum and of ores; a time-analysis of the continents, the distribution of principal volcanic areas and of sea-bottom sediments. On smaller scales, the changing geography of recfs, of evaporates and of aeolian sediments through geological timo is illustrated; also the Eocambrian tillites, the palaeoclimates of the Devonian and the floras and glaciation of the Permo-Carboniferous. Many of these syntheses have become familiar to British workers through the conferences organized at Newcastle by Professor Runcorn.

Finally, for Europe, South-west Asia, Asia in general, the South-west Pacific, Africa, the Americas and the South Polar region, separate geological maps at $1: 25 \mathrm{~m}$ are presented, followed by tectonic maps and geophysical and other data. The distribution of fossil fuels for each major region produces an interesting picture, but that of the metalliferous ores suggests merely a generalized scatter which does less than justice to these highly individualized concentrations.

A general colour-index folded in at the back of the volume provides a key to the geological maps. The standard of presentation is reasonable, but the liberal use of grey instead of black lines makes the cartography less attractive than it might be.

K. C. DunhaM

\section{USING STEELS}

The Technology of Ferrous Alloys for Ambient and Low-Temperature Use

By T. F. Pearson. (Newnes International Monographs on Materials Science and 'Technology.) 1'p. xvi +240 . (Hamlyn for Newnes Books: Feltham, Middlesex, 1968.) $70 s$.

The author introduces his subject briefly in the opening chapter, showing how it is incrcasing in practical importance. The book is then divided into four sections. Physical metallurgy and heat treatrnent principles are developed in the first part and are followed by a short section on the technology of steels which aims at illustrat. ing the historical development of brittleness in stcols and its dependence upon stcelmaking processes. In these two parts it would seem that the author tries to cover too large a field at the expense of fundamental detajls. In partieular, the short ehapter on stcelmaking processes could have been sacrificed to allow greater errophasis to be given to the principles of brittleness and toughness.

The third section surveys the types of fabricated steel products which are used in low temperature applications, illustrating the effect of tho materials' brittleness and toughness on the design of the product. A good chapter on welded products includes the deleterious effects of gases on the final properties, the concept of weldability and the application of these principles to design factors especially in the welding of steel plate.

The final section is concerned with the properties of wrought steels and, in particular, stcel plate. In fact, a major limitation of the book is that nearly all the practical examples are drawn from this, the author's chief interest. A summary of the properties of a wide range of steels is given with the effect of heat troatment on them. One chapter deals exclusively with steels for cryogenic purposes, including the problems associated with welding stainless and alloy stecls. The book concludes with a survey of testing methods used for examining steels for ambient and low temperatures. These are critically assessed as to their suitability for the properties being measured and the ease of specimen preparation.

The author has produced an excellent book in which he deals with the subject adequately from the theoretical standpoint and is also practically oriented with a wealth of data particularly useful to the metallurgist concerned in the design of steels for low temperature application.

\section{J. C. Billington}

\section{BOMBARDING SOLIDS}

\section{Ion Bombardment of Solids}

By G. Carter and J. S. Colligon. Pp. viii + 446. (Heinemann (Educational): London, June 1968.) 252s.

Ton bombardment of solids is a field which has occupied scientists for many years and has now grown into an important technological subject. For this reason alone, an up to date comprehensive but critical review of the subject is certainly necessary. It was clearly to this end that Carter and Colligon set out to write their book.

$\Lambda \mathrm{s}$ the authors acknowledge in their preface, no attempt has been made to be selective in the choice of material, with the result that the book contains a host of information gathered from numerous sources irrespective of their relevance to present day knowledge. This fact has undoubtedly affected the length of the book, which otherwise could have been considerably shorter. Generally, the authors have presented a fairly balaneed account of the many aspects covered by such a title as "Ion Bombardment of Solids". They have, however, concentrated on the basic physies of the various processes associated with the interaction of ion beams with solids; the numerous applications have received only superficial coverage.

The principal disappointment is the apparent gap between the time of writing and publication, for instance, there are only a few referenees more resent than 1964 . In this respect the book has missed out on the important advances made in channelling and on the latest controversies regarding the role of focused collision sequenees in sputtering. Further, the book has a disturbing number of petty errors; for example, in the references one finds $V$. Gonser and $U$. Gonser on successive lines.

In summary, a wealth of information on a variety of related phenomena is presented in a readable way, and as such, provides a valuable source of reference for both students and specialists.
R. S. NeLson 